\title{
Contribution of Industrial Work Practice Performance and Creativeness to the Academic Skill and Its Effect to the Outcome of Skill Competency Test of Computer and Network Technology Skill Package in Vocational High School
}

\author{
Ayu Septiana Pratiwi, Dwi Agus Sudjimat, Hakkun Elmunsyah \\ State University of Malang, Indonesia \\ ayus.pratiwi@gmail.com
}

\begin{abstract}
Skill Competency Test (UKK-Uji Kompetensi Keahlian) is one educational programme in Vocational High School to assess student's competency and skill as with the skill competency. Competency and skill students can be influenced by many factors. These can come from industrial work practice in DU/DI, a students creativity, and academic skill from learning activity in shcool. The study aims to reveral the contribution of several factor that affect to the outcome of skill competency in Vocational High School. Among factors that have been selected to be investigated is the industrial work practice in DU/DI, a students creativity, and cademic skill from learning activity in shcool. This study uses a quantitative approach. The research population was students at $12^{\text {th }}$ Grade of Computer and Network Technology Skill Package in Vocational High School of Tulungagung Regency for 293 students, is Vocational High School 1 Boyolangu, Vocational High School 1 Rejotangan, Vocational High School Sore Tulungagung, Vocational High School Veteran Tulungagung. Sample taking technique in this research used proportional random sampling. The research sample was 169 students. Data collection of this study is using instrumen test for academic skill, questionnaire for creativity and documentation for industrial work practice performance and outcome of skill competency. Data analysis is using descriptive analysis and path analysis with SPSS for windows on significant 0,05 . The results of this study: (1) there is a significant contribution between industrial work practice to the academic skill was 0,09(9\%); (2) there is a significant contribution between creativity to the academic skill was 0,003(3\%); (3) there is a significant contribution between industrial work practice to the outcome of skill competency was $0,025(2,5 \%)$; (4) there is a significant contribution between creativity to the outcome of skill competency was $0,002(2 \%)$; and (5) there is a significant contribution between academic skill to the outcome of skill competency was $0,003(3 \%)$. The conclution of this research is outcome of skill competency can be affected from industrial work practice, creativity and academis skill.
\end{abstract}

Keyword: Industrial work practice, creativeness, academic skill, outcome of skill competency test of computer

\section{Introduction}

Vocational High School (SMK-Sekolah Menengah Kejuruan) is one secondary level of formal education that serves as a place to prepare learners to be ready in entering the world of work and able to compete in this era development challenge. Peraturan Pemerintah Republik Indonesia No 17 Tahun 2010 about Education Management and Implementation, article 76 states that the goal of vocational high school is to make the students are able to achieve science and technology knowledge and profession vocational skill as with the needs of the world of work. Clarke \& Winch $(2007$, p.62) stated that vocational school is the effort of development, acceleration, and improvement of worker quality. While, Calhoun \& Finch (in Sonhadji, 2013, p.154) stated that vocational school is educational programme that directly related to the individual preparation in entering the world of work, by considering many technological changes which affect human culture and life. Therefore, vocational education has important role in giving special skill for individu to seek job opportunity or start a business in the future. It is in line with the statement of Jayanti \& Sudarwanto (2012, p.2) where, particularly, vocational education prepared for individu to enter the world of work either starting a new business or seeking job opportunity.

The attempt of government in preparing ready to work, smart, and competitive graduates conducted by Skill Competency Test (UKK-Uji Kompetensi Keahlian). According to Suhartadi (2011, p.157), Skill Competency Test is set of activity that conducted as with the competency standard to assess student's competency. This Skill Competency Test that conducted in Vocational High School is part of national examination which becomes the indicator of graduate competency standard achievement and for stakeholders, it is made as information over the competency that owned by the worker candidate (Perwitasari, 2013, p.425). Education in Vocational High School with Skill Competency Test programme in preparing ready to work and skilled 
graduates is necessary to be revised. It is due to many Vocational High School graduates are still unable to meet the demand of job opportunity as with the skills. Based on Badan Pusat Statistik (2016), total Vocational High School graduate in 2016 was 1,296,246 students and it is still lack of the graduate of Information and Communication Technology for 50,268 students. It implies that there is a gap between skill and knowledge that owned by students in entering the world of work and industry. Computer and Network Technology (TKJTeknik Komputer dan Jaringan) is one of skill package in Vocational High School. Based on the Struktur Kurikulum 2013 SMK Paket Keahlian TKJof: group A (compulsory), group B (compulsory), and group C (specialization). This group C (specialization) divided into 3 (three) groups: group C1 (basic of skills), group C2 (basic of skill programming), and group C3 (skill package).

Industrial Work Practice (Prakerin-Praktik Kerja Industri) is education and training that conducted to the students in Business or Industrial Field. According to Lestari \& Siswanto $(2015$, p.18), industrial work practice is part of learning programme that must be conducted by every student in the world of work as the realization of educational system implementation in Vocational High School, which is Dual Education System (PSG-Pendidikan Sistem Ganda). In the technical guidance of Dual Education System implementation by Vocational High School students, it states that industrial work practice is productive skill practice that conducted in the industrial field, which is activity in teaching about production and service (Ministry of National Education, 1997). The implementation of industrial work practice will educate students to mastering competency as with their field directly in the world of work and industry. Besides educating the students with competency according to their field, the students also educated about personality development, academic potential, and basic skills in the world of work. The implementation of industrial work practice also demonstrates student's productive skill ability. According to Budiyana (2010, p.24), student's competency performance during the industrial work practice can be viewed from many aspects such as work quality, accuracy, initiative, capability, and good communication. However, student's performance during industrial work practice is still lack of supervising either from industrial supervisor or teacher. Thus, the student's performance during industrial work practice is still not maximal and it seems like they are just playing in the work or industrial field.

Students of Computer and Network Technology demanded to use right brain which related to the creativeness in facing learning process that uses their logic and physical work. Creativeness is feeling process, creating idea or hypothesis, and communicating causal relationship in modifying and testing the hypothesis (Turkmen, 2015, p.75). While, according to Tsai (2013, p.2), creativity related with 4 (four) paradigm: creative person, cognitive, environment supports creativity, and product of creativity development. According to Ramirez \& Ganaden (2008, p.25), activity components can be developed in the classroom using various strategy as follow: visualization, student's thinking ability, more straight forward in making question, considering alternatives from personal view, contributing new ideas, and problem solving. Academic skill is the development of rational thinking skill which applied to know the extent of $t$ student in mastering material that been taught in the school. Pasternak $(2013$, p.3) defined that academic skill related with many factors: disciplinary, diligence, ability in arranging schedule, planning the goal, and competitiveness. Based on the overview above, the researcher wanted to look for contribution between industrial work practice performance and creativeness variable to the academic skill and its effect to the outcome of Skill Competency Test in Vocatinal High School Tulungagung Regency.

\section{Literature Review}

Industrial Work Practice Performance: Industrial work practice is part of learning and training process in Vocational High School. Sya'diyah $(2012$, p.4) stated that industrial work practice is professional skill education that achieved directly in the world of work. According to Schuler in Budiyana (2010, p.24), student's performance during the industrial work practice can be identified from many aspects: (1) work quality; (2) work quantity; (3) cooperation; (4) knowledge about the job; (5) reliability; (6) attendance and punctuality; (7) industrial knowledge and goal; and (8) related things and consideration.

Creativeness: Creativity is a condition, attitude, ability, and flexibility of thinking to result an idea in problem solving (Indriati, 2013, p.5). According to Sudjimat (2014, p.310) many creativity indicators as follow: (1) 
ideal fluency; (2) originality; (3) critical thinking; (4) enjoyment; (5) aesthetic; (6) risk-taking; and (7) cyclical procedure.

Academic Skill: Marwiyah (2012, p.87) stated that academic skill is scientific thinking ability based on self development of rational thinking skill in the global life skill. This academic skill directly can be seen from direct instruction in the learning with the student's ability.

Skill Competency Test: Pratiwi (2013, p.2) stated that Skill Competency Test (UKK) used to know the extent of student's maturity level in receiving and mastering material. Competency test also presents information over student's competency to the stakeholder (Rozaq, 2012, p.1). The purpose of Skill Competency Test can be seen in the Badan Penyelenggaraan Uji Kompetensi Keahlian UKK SMK Tahun Pelajaran 2014/2015 as follows: (1) assisting the students in obtaining competency certificate in order to make them easily to enter the world of work and industry; (2) knowing competency achievement of Vocational High School students when it is assessed from industrial standard side; (3) giving feedback to the process of education and training implementation in Vocational High School; and (4) gaining competency test implementation pattern that refers to the industrial standard (international).

\section{Methodology}

This research used quantitative research method with analysis method of path analysis. This research aims to know contribution between exogenous variable (industrial work practice performance $\left(\mathrm{X}_{1}\right)$ and creativeness $\left(\mathrm{X}_{2}\right)$ and endogenous variable (outcome of Skill Competency Test (Z)). This research also included intervening variable of academic skill (Y).

\section{FIgure 1: The Relationship among Variables}

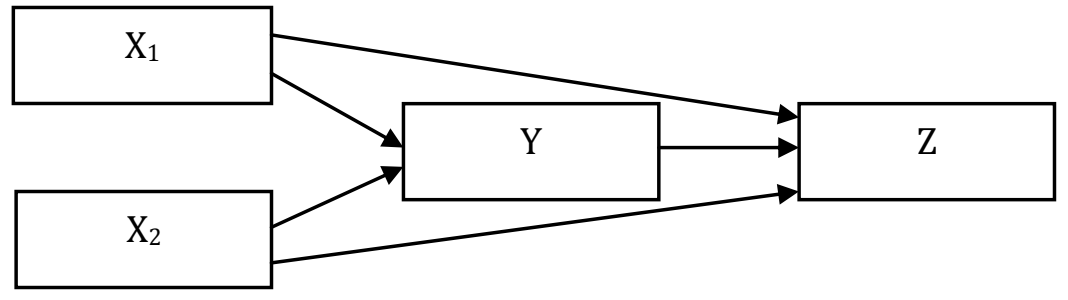

Population and Sample: The research population was students at $12^{\text {th }}$ Grade of Computer and Network Technology Skill Package in Vocational High School of Tulungagung Regency for 293 students. Sample taking technique in this research used proportional random sampling. The research sample was 169 students.

Research instrument: Instruments that used in this research were questionnaire, test, and documentation. Questionnaire instrument used to know student's creativeness, test instrument used to assess student's academic skill, and documentation used to know the result of industrial work practice and the outcome of Skill Competency Test.

Data Analysis: Data analysis used to know contribution between $\mathrm{X}_{1}, \mathrm{X}_{2}, \mathrm{Y}$, and $\mathrm{Z}$ variable using path analysis

\section{Result and Discussion}

Data description: Data description was description to each research variable (creativeness, industrial work practice performance, academic skill and outcome of skill competency test) which including mean, median, modus, standard deviation, range, minimum score, maximum score, and frequency distribution. Data description can be seen in Table 1. 
Tabel 1: Data Description to Each Research Variable

\begin{tabular}{|c|c|c|c|c|c|c|c|}
\hline No & Variable & Mean & Median & $\begin{array}{l}\text { Standard } \\
\text { Deviation }\end{array}$ & Range & Min & Max \\
\hline 1. & Industrial Work Practice $\left(\mathrm{X}_{1}\right)$ & 83.28 & 83.28 & 5.560 & 30 & 65 & 95 \\
\hline 2. & Creativeness $\left(\mathrm{X}_{2}\right)$ & 81.44 & 81.00 & 7.025 & 33 & 62 & 95 \\
\hline 3. & Academic Skill (Y) & 78.86 & 79.00 & 5.183 & 25 & 69 & 94 \\
\hline 4. & Outcome of Skill Competency Test (Z) & 85.01 & 85.00 & 5.560 & 29 & 69 & 98 \\
\hline
\end{tabular}

Hypothesis: Hypothesis test conducted by using path analysis. Path analysis used to describe and test relationship model among causal variables.

First Hypothesis: The first hypothesis stated that there is significant contribution between industrial work practice performance to the student's academic skill in Vocational High School of Tulungagung Regency. Based on the research result, student's industrial work practice performance had contribution of $0.09(9 \%)$ to the academic skill. It was in line with the statement of Pratiwi $(2013$, p.10) that there is positive effect between student's industrial work practice performance in the world of business and industry to the student's academic skill.

Second Hypothesis: The second hypothesis stated that there is significant contribution between student's creativeness to the student's academic skill in Vocational High School of Tulungagung Regency. Based on the research result, contribution of creativeness to the student's academic skill was 0.003 (3\%). Indriati (2013, p.5) stated that student's creativeness is a condition, attitude, ability, and flexibility of thinking to result a new idea. This student's creativeness would help to solve problems during the learning process.

Third Hypothesis: The third hypothesis stated that there is significant contribution between industrial work practice performance to the Skill Competency Test of students in Vocational High School of Tulungagung Regency. Based on the research result, this industrial work practice had contribution of $2.5 \%$ to the outcome of Skill Competency Test. It was in line with the research of Jayanti \& Sudarwanto (2012, p.16) that industrial work practice performance variable has positive effect to the outcome of Skill Competency Test for 0.861 .

Fourth Hypothesis: The fourth hypothesis stated that there is significant contribution between creativeness to the outcome of Skill Competency Test of students in Vocational High School of Tulungagung Regency. Based on the research result, contribution of creativeness to the outcome of Skill Competency Test was 2\%. It was in line with the research of Dewi et al. (2013, p.9) that creativeness has positive and significant contribution to the outcome of Skill Competency Test for 35.5\%. A good learning process will give effect to the improvement of student's creativeness if there is any opportunity in thinking, stating opinion, and taking decision alternatively (Saparahayuningsih, 2010, p.2).

Fifth Hypothesis: The fifth hypothesis stated that there is significant contribution between academic skill to the Skill Competency Test of students in Vocational High School of Tulungagung Regency. Based on the research result, academic skill had contribution of 3\% to the outcome of Skill Competency Test. It was in line with the research of Aldilla et al. (2016, p.16) that student's academic skill can be seen through practice implementation, in which students in Public Vocational High School (SMK N) 3 Serang have good category with the average score of 77.7. Therefore, by seeing student's academic skill it also could be seen about the student's skill during practice implementation and the outcome that they achieved.

\section{Conclusion and Suggestions}

Based on research and discussion above, it could be concluded as follows: (1) industrial work practice performance had significant contribution to the academic skill was $9 \%$. The higher student's performance that gained in the world of business and industry, the larger knowledge that they gained; (2) student's creativeness had significant contribution to the academic skill was 3\%; (3) industrial work practice had significant contribution to the outcome of Skill Competency Test was 2,5\%; (4) creativeness had significant contribution to the outcome of Skill Competency Test in Vocational High School was 2\%; and (5) academic skill had significant contribution to the outcome of Skill Competency Test was 3\%. The implementation of 
Skill Competency Test in Vocational High School used to assess student's competency and skill, thus Skill

Competency Test also demanded the students to know about their gained former knowledge.

Suggestion: Based on conclusion in this research for Public Vocational High School Tulunggagung Regency, it is sugested as follow: it needs development for teachers in learning class with approprite learning models, and guidance for students who have difficulty in learning.

\section{References}

Aldilla, S. B., Marianingsih, P. \& Nulhakim, L. (2016). Profil Kecakapan Akademik Siswa Melalui Praktikum Berbasis Guided Inquiry pada Konsep Sistem Pernapasan. JPPI, 2(1), Juni 2016, Hal 1-17, e-ISSN 2477-2038

Badan Penyelenggaraan Uji Kompetensi Keahlian UKK SMK Tahun Pelajaran 2014/2015. (Online). (www.mustofatope.file.wordpress.com/2015/03/pedoman-ukk2015.pdf), diakses 25 Desember 2015.

Badan Pusat Statistik. (2016). Berita Resmi Statistik Keaadan Ketenagaan. No.48/05Th.XVIII, 20 Oktober 2016.

Budiyana, I. (2010). Hubungan Motivasi Belajar, Kematangan Siswa, Prestasi Belajar, dan Kerja Praktik Industri dengan Kesiapan terhadap Dunia Kerja Siswa Bidang Keahlian Teknik Bangunan Se-Malang Raya. Tesis tidak diterbitkan. Malang: PPS UM.

Clarke, L. \& Winch, C. (2007). Vocational Education International Approach, Development and System. New York: Routledge.

Dewi, K. T. S., Yudana, I. M. \& Dantes, N. (2013). Kontribusi Minat Kewirausahaan, Kreativitas, dan Persepsi tentang Pasar Kerja Non Formal terhadap Hasil Belajar Praktek Siswa Progra, Keahlian Tata Busana pada SMK N 3 dan 4 Denpasar tahun 2012.E-jurnal Program Pascasarjana Universitas Pendidikan Ganesha, 4(2), Tahun 2013.

Indriati, D. (2013). Kontribusi Kreativitas, Kemampuan Awal dan Gaya Belajar terhadap Prestasi Belajar Praktek Instalasi Home Theater Siswa SMK Muhammadiyah 3 Yogyakarta. Skripsi dterbitkan. Yogyakarta: UNY.

Jayanti, R. \& Sudarwanto, T. (2012). Pengaruh Pelaksanaan Praktek Kerja Industri (Prakerin) terhadap Hasil Uji Kompetensi Keahlian Siswa Kelas XII TN SMK Negeri 2 Nganjuk. Jurnal Pendidikan Tata Niaga (JPTN), 2(2), Tahun 2014.

Lestari,S. \& Siswanto, B. (2015). Pengaruh Pengalaman Prakerin, Hasil Belajar Produktif, dan Dukungan Sosial terhadap Kesiapan Kerja Siswa SMK. Jurnal Pendidikan Vokasi, 5(2), Juni 2015

Marwiyah, S. (2012). Konsep Pendidikan Berbasis Kecakapan Hidup. Jurnal FALASIFA, 3(1) Maret 2012.

Pasternak, R. (2013). Discipline, Learning Skill and Academic Achievement. Journal of Arts and education. Full Length Research Paper, 1(1), 1-11, June 2013

Peraturan Pemerintah Republik Indonesia No 17 Tahun 2010 tentang Pengelolaan dan Peneyelenggaraan Pendidikan. (Online). (kelembagaan.ristekdikti.go.id/wp-content/uploads/2016/08/PP172010Lengkap.pdf), diakeses 08 Nopember 2016.

Perwitasari, D. (2013). Hubungan Fasilitas Praktikum TKJ di Sekolah, Kesesuaian Tempat Prakerin, dan Kompetensi TKJ Siswa dengan Hasil Uji Kompetensi Keahlian. Jurnal Pendidikan Sains, 1(4), Desember 2013, Hal 425-431.

Pratiwi, S. (2013). Pengaruh Praktek Kerja Industri dan Motivasi Kerja terhadap Hasil Uji Kompetensi Siswa SMK N Tembarak. Skripsi diterbitkan. Yogyakarta: FT UNY.

Ramires, R. P. \& Ganaden, M. S. (2008). Creative Activities and Students' Higher Order Thinking Skills. Education Quarterly, 66(1), 22-33.

Rozaq, A. (2012). Studi Kasus Kesiapan Pelaksanaan Uji Kompetensi Mata Pelajaran Perakitan PLC pada Kompetensi Keahlian Teknik Otomasi Industri SMK Negeri Pati. Skripsi diterbitkan. Yogyakarta: FT UNY.

Saparahayuningsih, S. (2010). Peningkatan Kecedarsan dan Kreativitas Siswa. Jurnal Kependidikan Dasar, 1(1), September 2010

Sonhadji, A. (2013). Manusia, Teknologi, dan Pendidikan Menuju Peradaban Baru. Malang: UM Press.

Struktur Kurikulum 2013 SMK Paket Keahlian TKJ. (Online), (http://www.tkjsmk.net/2014/08/strukturkurikulum-2013-paket-keahlian.html), diakses Desember 2015 
Sudjimat, D. A. (2014). Perencanaan Pembelajaran Kejuruan. Malang: UM Press.

Suhartadi, S. (2012). Pengembangan Model Perangkat Uji Kompetensi di Sekolah Menengah Kejuruan Teknologi dalam Bidang Permesinan. Jurnal Teknologi dan Kejuruan, 34(2), 155-164.

Sya'diyah, N. K. (2012). Pengaruh Pengalaman Praktek Industri (Prakerin) terhadap Kesiapan Kerja Peserta Didik Program Keahlian Administrasi Perkantoran di SMK Taruna Jaya Gresik. Jurnal Administrasi Perkantoran (JPAP), 2(2), 2014.

Tsai, K. C. (2013). Leadership Recipes for Promoting Student's Creativity. International Journal of Humanities and Social Science, 3(5), March 2013.

Turkmen, H. (2015). Creative Thingking Skills Analyzes of Vocational High School Students. Journal of education an instruktional studies in the word, 5(1), article: 10, ISSN: 2146-7463. 